\title{
BHADARWAHI: A TYPOLOGICAL SKETCH
}

\section{Amitabh Vikram DWIVEDI}

Shri Mata Vaishno Devi University, India

amitabhvikram@yahoo.co.in

\begin{abstract}
This paper is a summary of some phonological and morphosyntactice features of the Bhadarwahi language of Indo-Aryan family. Bhadarwahi is a lesser known and less documented language spoken in district of Doda of Jammu region of Jammu and Kashmir State in India. Typologically it is a subject dominant language with an SOV word order (SV if without object) and its verb agrees with a noun phrase which is not followed by an overt post-position. These noun phrases can move freely in the sentence without changing the meaning of the sentence. The indirect object generally precedes the direct object. Aspiration, like any other Indo-Aryan languages, is a prominent feature of Bhadarwahi. Nasalization is a distinctive feature, and vowel and consonant contrasts are commonly observed. Infinitive and participle forms are formed by suffixation while infixation is also found in causative formation. Tense is carried by auxiliary and aspect and mood is marked by the main verb.
\end{abstract}

Keywords: Indo-Aryan; less documented; SOV; aspiration; infixation

\section{Povzetek}

Članek je nekakšen daljši povzetek fonoloških in morfosintaktičnih značilnosti jezika badarvahi, enega izmed članov indo-arijske jezikovne družine. Badarvahi je manj poznan in slabo dokumentiran jezik $z$ območja Doda $v$ regiji Jammu $v$ Kašmirju. Tipološko je zanj značilen dominanten osebek in besedni red: osebek, predmet, povedek. Glagoli se povečini ujemajo $s$ samostalniškimi frazami, ki lahko v stavku zavzemajo katerikoli položaj ne da bi spremenile pomen stavka. Nadaljna značilnost jezika badarvahi je tudi to, da indirektni predmeti ponavadi stojijo pred direktnimi predmeti. Tudi aspiracija je, tako kot $v$ drugih indo-arijskih jezikih, ena izmed pomembnih lastnosti jezika badarvahi, medtem ko je nazalizacija (nosnjenje) tudi pomenskorazločevalna lastnost. Članek obravnava tudi medpone, opisuje njihovo uporabo $v$ primerjavi $\mathrm{s}$ priponami, glagole in izražanje glagolskega časa in drugo.

Ključne besede: indo-arijska jezikovna družina; slabo dokumentiran; struktura SOV (osebek; predmet; povedek); aspiracija; medpone 


\section{Introduction}

Bhadarwahi language is spoken (Indo-European family group language) in the region of Bhadarwah (the ancient name Bhaderkasi) of Doda district in eastern part of Jammu region of Jammu and Kashmir state in India. This district is surrounded by Anantnag district of Kashmir on its north, Kishtwar district in the northeast, Chamba area of Himachal Pradesh in the south, Kathua district in the south, Udhampur district in the southwest and Ramban district in the west. Siraji is also a major language of Doda district, but it is spoken mainly in Doda town and its surrounding villages. The population of Doda district in Jammu and Kashmir was 409,576 in 2011 according to census of India, out of which, $52.0 \%$ were males and $48.0 \%$ were females. Bhadarwahi speakers' population in 2011 was 250, 000 approximate.

The standard Bhadarwahi is spoken in the Bhadarwah town of Doda district of Jammu \& Kashmir state of the Republic of India. This language shows lexical similarity with Pangwali, Siraji, Padri, and Bhalesi languages. SIL International in 2009 documentation for Bhadarwahi identified Bhadarwahi as bhd.

Table 1: SIL International 2009 documents Bhadarwahi as

Identifier: bhd

Name: Bhadarwahi

Code: ISO 639:3

Scope: Western Pahari language
Dialects: Bhalesi and Padari

Spoken by: Hindu \& Muslim community

Script: Devanagari \& Arabic

\subsection{Bhadarwahi under Western Pahari Languages}

Bhadarwahi language comes under Northern Zone Western Pahari languages. The word 'pahari' (hilly) has been derived from Hindi word 'pahar' (mountain). Western Pahari is a cluster of 17 different languages which are spoken in Jammu and Kashmir, Uttarakhand, Uttar Pradesh, Delhi, Punjab, Madya Pradesh, and Himachal Pradesh regions. The word order of Bhadarhawi language is SOV. Out of these 17 Western Pahari languages Bhattiyali, Bilaspuri, Chambeali, Churhahi, Hinduri, Kangari, Kinnauri, Mandeali, Pahari-Mahasu, Pahari-Kullu, Sirmauri, and Pangwali are spoken in Himachal Pradesh state of India; and Gaddi is spoken in 6 Indian states namely Delhi, Punjab, Himachal Pradesh, Madhya Pradesh, Jammu and Kashmir, and Uttar Pradesh; and Dogri is spoken in Jammu of Jammu and Kashmir state; and Jaunsari is spoken in Uttarakhand state; and Pahari-Potwari is spoken in Pakistan and Kashmir state.

Table 2: Lexical similarity of Bhadarwahi with other Pahari languages

\begin{tabular}{|c|c|c|c|}
\hline Pangwali & Siraji & Padri & Bhalesi \\
\hline $45 \%$ & $30 \%$ & $60 \%$ & $70 \%$ \\
\hline
\end{tabular}




\subsection{People and language}

The origin of Bhadarwahi can be traced back to the ancient time when Jammu and Kashmir was a Hindu (majority of the population was the follower of Hindu religion) state. As Buddhism started to spread around $400 \mathrm{BC}$ in this region, the Buddhist priests searched a language other than Sanskrit to spread the teachings of Buddha. Buddhists adapted Pahari as a language of their preachings and various scripts were introduced to write the language such as Duggal, etc.

This was the climax of Pahari language. However, with the fall of Buddhism and again with the rise of Hinduism in Kashmir proved to be a fall of Pahari language. Pahari language was abandoned and it remained at the mercy of the local people.

Bhadarwah is also known as 'Nagon ki Bhoomi' (land of snakes). The Bhadarwah town was known as Hettary Nagar and prior to that, there were other towns namely Donga and Udho Nagar. Both the nagars were situated around the villages which is about $3 \mathrm{kms}$ in the east of present Bhadarwah town.

The poets and singers such as Kailash Mehra Sadhu, Bashir Ahmed Mastana, Ghulam Nabi Goni, Basir Charag, and Master Dina Nath are mainly responsible for the development of the oral culture of this language. Bhadarwah tehsil has its own radio station. Bhadarwah programme is broadcasted on each Sunday at 8'o clock on local radio station.

\subsection{Previous Studies}

In 1916, Sir George Grierson (Linguistic Survey of India, Vol. VIII, Part-I) made a mention of Bhadarwahi as one of the dialects of Kashmiri. He observes that the Kashmiri language is the language of the Valley of Kashmir. In a dialect form it has spread south-west into the valley of Kashtwar, and to the south it has flowed over the Pir Panjal Range into the lower hills lying north of the river Chinab, where it reappears in a number of mixed dialects (such as Bhaderwahi, Kishtwar, Siraji, Poguli and Rambani). In 2013, Dwivedi documented this language in the descriptive grammar tradition.

\section{Phonology}

\subsection{Vowels}

Bhadarwahi has an 11 vowels system as given in Table 3. In terms of vowel height, there are four high vowels /i:/, /i/, /u:/ and /u/, and five mid vowels /e/, /e:/, /ə/, /o:/, and /o/, and four low vowels /ə/, /o/, /a/, and /a:/. In terms of backness, there are four front vowels /i:/, /i/, /e/ and /e:/, one central vowel /ə/, and six back vowels /u:/, /u/, /o:/, /o/, /a/, and /a:/. 
Table 3: Vowels in Bhadarwahi

\begin{tabular}{|l|c|c|c|}
\hline & Front & Central & Back \\
\hline High & $\mathrm{i}:$ & & $\mathrm{u}:$ \\
\hline Lower High & $\mathrm{i}$ & & $\mathrm{u}$ \\
\hline Mid & $\mathrm{e}, \mathrm{e}:$ & & $\mathrm{o}:$ \\
\hline Lower Mid & & & $\mathrm{o}$ \\
\hline Low & & & $\mathrm{a}, \mathrm{a}:$ \\
\hline
\end{tabular}

There are five pairs of short and long vowels: /i/ and /i:/, /a/ and /a:/, /e/ and /e:/, /u/ and /u:/, and /o/ and /o:/. As in: dla 'marriage', dla: 'brother', kori 'where', kori: 'a leper', kero 'did', ke:ro 'how', mujo 'mother's sister's husband, mu:Jo 'mouse', horo 'and', and ho:ro 'another'. Stress is not a phonemic feature in Bhadarwahi language. Generally a syllable having a consonant cluster gets stressed. As in: kənne 'and', dzək ho 'bite', hədd 'bone' In a di-syllabic vowel where both the syllables having vowel sounds (if vowel is of same length), the first one gets stressed. As in: pino 'to drink', sukk ${ }^{\mathrm{h}}$ ' $d r y$ ', $\mathrm{k}^{\mathrm{h}}$ ano 'to eat'. The first syllable gets stressed if it is a low front vowel or a back vowel. As in: dure 'far', deli 'Delhi'. The second syllable gets stressed when the first syllable having a short vowel. As in: həro 'green', həsno 'to laugh', and dərja 'river'. In a tri-syllabic word if first and third syllable having long vowel and the middle vowel is short; the initial vowel gets stressed.

\subsection{Consonants}

There are 37 consonants sounds in the Bhadarwahi language. The eight points of articulation are attested, viz. bilabial, dental, alveolar, palatal, velar and glottal. There appears distinctive voicing and aspiration in this language. Aspiration is a prominent feature of this language; twelve consonant sounds show this feature. The palatal nasal sound occurs only in the word middle position and nasal velar sound occurs in the word middle and the word final position. Bhadarwahi has a palatal fricative sound ç which is not found in Hindi and Dogri.

Bhadarwahi consonant sounds geminate in the word middle and the word final position. The gemination of two aspirated sounds makes the first sound unaspirated. Such as, pəttərũ 'back', hədd 'bone', kənn 'ear', səpp 'snake', çəpp 'hide', bətftJo 'child', tJəkki 'water-mill', məkku 'axe', Jukku 'dry', and pəkk'o 'fan'. 
Table 4: Consonants in Bhadarwahi

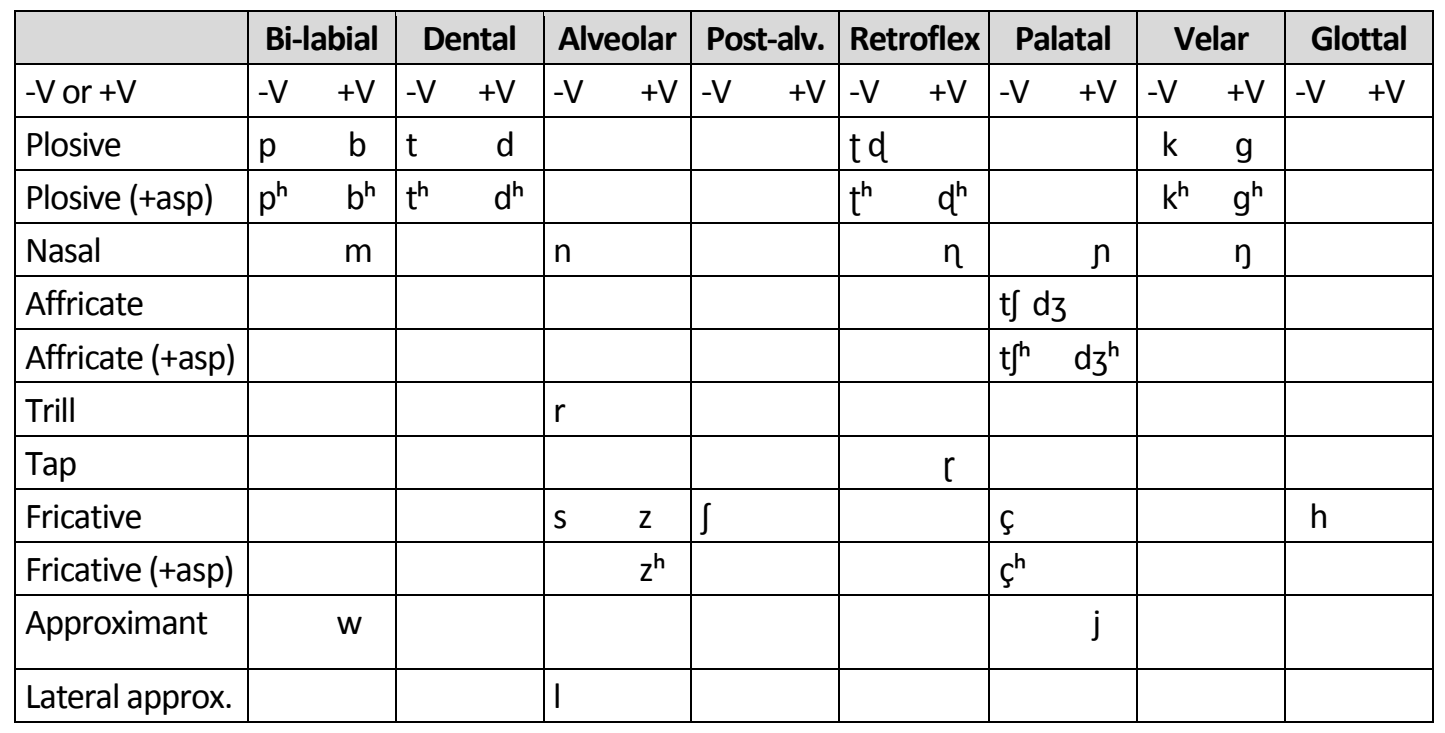

\subsection{Phonotactics}

The simple vowels are found in all positions. Most of the vowels can be nasalized. Nasalization is a distinctive feature in Bhadarwahi; it has a phonemic status, ta 'and', tã 'then', ba 'hit', bã 'forearm', zid 'obstinacy', zĩd 'darling', dhou 'washed', dhoũ 'washed' (past participle), sei 'right' and seĩ 'from/with'. Vowel contrast is also attested in the Bhadarwahi language as tənki 'water-tank'and tənki: 'water-tanks', nəlko 'tap' and nəlki 'yarn thread', ka: 'which' and ki: 'why', ded 'sister' and da:d 'grandmother' (paternal), and go:r 'cow shed' and gur 'sugar'.

Almost all consonants are attested in all positions, except [n], [n] and [n]. Consonant clusters can occur at word initial, word middle, and word final position. For example, consonant cluster (consonant + semi-vowel) at word initial, kw: kwant] 'wife', gj: gjani 'sikh priest' etc, consonant cluster (velar stop + consonant) at word middle position, kk: dəkku 'tradition dance of Bhadarwah', kk': kukk ${ }^{\mathrm{h}} \mathrm{di}$ 'hen', kr: kakra 'crab', etc, consonant cluster (affricate + consonant) at word middle position, $\mathrm{t} f \mathrm{k}$ : hit $\int \mathrm{ki}$ 'hiccup', $\mathrm{t} \mathrm{t} \mathrm{t}$ : kət $\mathrm{t} \mathrm{t} \mathrm{u}$ 'unripe', $\mathrm{t} / \mathrm{t} \mathrm{f}^{\mathrm{h}}$ : ət $\mathrm{ft} \mathrm{f}^{\mathrm{h}} \mathrm{a}$ 'yes' etc, consonant cluster (retroflex + consonant) at word middle position, tk: utka 'bounce' and tt: kəttər 'strong belief' etc, consonant cluster (dental + consonant) at word middle position, $\mathrm{t}$ : pətlo 'thin', tt: səttu 'a dish' etc, consonant cluster (bilabial + consonant) at word middle position, pk: tfipkəli 'gecko', pt: tfəpto 'flat', pn: $d^{\text {hh }}$ upno 'to lock', etc, consonant cluster (nasal + consonant) at word middle position, nk: th ${ }^{\text {h }}$ 'to 'coin', nk': pənnk $k^{\mathrm{h}} \mathrm{o}$ 'fan', etc, consonant cluster (continuant + consonant) at word middle position, jt: rajto 'a yoghurt dish', wr: nəwrate 'a nine day religious festival' etc, consonant cluster (liquid + consonant) at word middle position, Ik: nəlki 'thread roll', Ig: $\mathrm{p}^{\mathrm{h}}$ algun 'last month of Hindu calendar' etc, and consonant cluster (sibilant + 
consonant) at word middle position, sk: nəskwar 'a local tobacco' and sr: nasri 'a name of a place'.

\subsection{Intonation}

There are four major types of intonational patterns in Bhadarwahi language. They are: high-fall, high-rise, rise-and-fall, and mid-level.

\subsubsection{High-fall in statements}

1. aũ huna məze mə aĩ

I.1.SG now good in am.PRES.SG.

'I am fine now.'

\subsubsection{High-rise in interrogatives}

2. kun tus $m \tilde{I}$ pəsənd kerte $\partial t^{\mathrm{h}}$ what you me like do AUX 'Why do you like me?'

\subsubsection{Rise and fall in information questions}

3. te kun kerte

you.2.SG what do.PRST

'What does he do?'

\subsubsection{Mid level in imperative}

4. i kəm ker (impolite)

this work do

'Do this work.'

\subsection{Canonical form}

The canonical form of Bhadarwahi syllable is CCVCCC. The eight types of syllable found in Bhadarwahi are:
$\mathrm{V}$
i: 'this', u: 'that', o 'oh', etc.
VC
ed3 'come', a:n 'bring', ut 'get up'
VCC
$\mathrm{uk}^{\mathrm{h} I}$ 'a utensil to crush nut', 'utr 'get down', etc.
$\mathrm{CV}$ kha: 'eat', gə 'go', zo 'say', mə 'not', etc.
$\mathrm{CCV}$ dla 'marriage', dla: 'brother', etc.
CVC na:I 'neck', kun 'what', sək 'doubt', etc.
CVCC çəpp 'hide', səpp 'snake', kənn 'ear', etc.
CVCCC mantl 'chant', antl 'inside', hejdl 'turmeric', etc. 
The vowel is the obligatory element, whereas the consonants are optional. The nucleus is always occupied by the vowels whereas onset and positions are occupied by consonants. The coda position can have up to three consonants, but the onset position can have up to two consonants

\section{Morphology}

Bhadarwahi allows prefixing, suffixing and infixing. Prefixation and suffixation are employed in derivational and inflectional morphology where as infixation converts a verb into a causative verb. I will be presenting the morphology into four subsections, viz. nouns and nominal morphology, adjectives, verb morphology and adverbs and other categories.

\subsection{Nouns and nominal morphology}

Bhadarwahi nouns are inflected for gender, number, and case by morphosyntactic categories. Nouns are masculine or feminine, and count or non-count. All nouns in Bhadarwahi are assigned a grammatical gender, which may or may not coincide with natural gender e.g. pəkk ${ }^{\mathrm{h}} \mathrm{o}$ ' $\mathrm{fan}^{\prime}$ ' is masculine; andəç 'eye' is feminine. The distribution of gender to inanimate objects is arbitrary, i.e. any inanimate object may get either masculine or feminine gender and we can't reason why we are assigning either masculine or feminine to them. Human and animal nouns sometimes have a single lexical form which represents both the genders as in kaw 'crow', dlag 'cheetah', bəcco 'kid', etc. A borrowed noun from a foreign language also takes only one form to represent either of the genders e.g. graund 'ground'. Common nouns inflect for gender, number and case. Proper nouns are assigned to specific gender categories and remain the same in all numbers and cases.

Bhadarwahi has two genders: masculine and feminine. Both animate nouns and inanimate nouns get a gender. According to Masica (1991: 219): "In the New IndoAryan...gender is an inherent and classificatory property of one class of words (nouns) and a variable or inflectional property of others (adjectives, certain verbal forms, sometimes pronouns and adverbs), and one extremely important postpositions."Assigning gender to nouns is arbitrary. Abstract nouns generally do not inflect for numbers with some exception, but concrete nouns inflect. Non-count concrete nouns are used with partatives e.g. the gender formation involves two processes: (a) suffixation, and (b) phonological changes (suppletion, etc.).

Most males are masculine nouns. Most of the masculine nouns get suffixed with /o/ sound, and the rest is consonant ending. For example, ghoro 'horse', t tat $\int 0$ 'uncle',

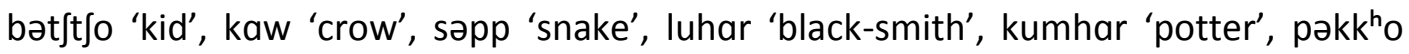
'fan' alike. Most females are feminine nouns. Most of the feminine nouns get suffixed with /i/ sound, and rest are consonant ending, such as ghori 'mare', t $\int a t \int i$ 'aunt',

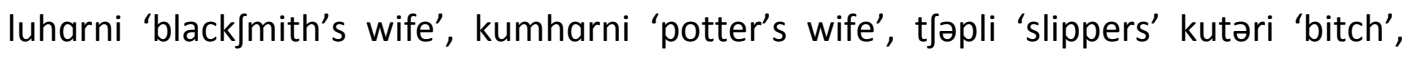


bəçç ${ }^{\text {hi }}$ 'cow' etc. There are nouns which are inherently masculine or feminine as mitl 'friend' a masculine noun (used for both masculine and feminine), bidali 'ant' a feminine noun (used for both masculine and feminine), etc.

\subsubsection{Semantic classification and nouns}

The days of the week are masculine: tfəndərbar 'Monday'. Trees and cereals are generally masculine: pipəl 'fig-tree', əna:r 'pomegranate, t5 ${ }^{\text {holo }}$ 'gram' but there are exceptions also in kukəri 'maize', dleik 'neem-tree', etc. are feminine. Names of the languages are feminine: hindi 'Hindi', inlif 'English', b' Jewels are masculine: sonnu 'gold', Iũo 'iron', moti 'pearl', hiro 'diamond', etc. Names of spices are feminine: pipali 'chilly', sõp ${ }^{\text {h } ~ ' f e n n e l ', ~ l o n ~ ' c l o v e ', ~ i l a t f i ~ ' c a r d a m o m ', ~ e t c . ~}$ Names of the mountains are masculine: trikuta 'Trikuta-hills', pi:r-pəndzal 'Pir-Panjal', himgiri 'Himalayas', etc.

\subsubsection{Size and Gender}

The size of the things is also responsible for assigning gender, e.g. pəhar 'mountain' is masculine, whereas pəhari 'small-mountain' is feminine.

\subsubsection{Derivation of feminine nouns}

Many feminine nouns are derived from masculine nouns by suffixation, and phonological changes such as vowel alteration. As in: ra:kəJ 'demon' (M) and ra:kəJəni 'female-demon'(F), ba:ndər 'monkey' (M) and ba:ndri 'female-monkey', dhobi 'washer-man' (M) and dhobən 'washer-woman'. Feminine suffixes are: əпi, әп ani, i, ni, and ni.

\subsection{Pluralization}

The vowel sounds $/ \mathrm{a} /, / \tilde{\mathrm{a}} /, / \mathrm{i} /$, and $/ \tilde{\mathrm{I}} /$ are generally employed as a suffix for the pluralization in Bhadarwahi. But the word final and medial vowel also alters and changes in /e/, /ẽ/, and /a:/. As in: məm 'father-in-law'and məma 'fathers-in-law',

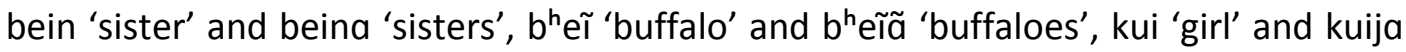

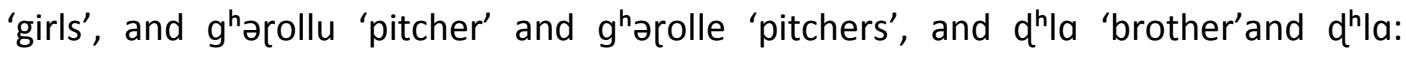
'brothers', etc.

\subsection{Number and Case}

In Bhadarwahi every noun has six forms that change according to the number (singular and plural) and case (nominative, oblique, and vocative). The forms of some of these look similar but they have different functions in a sentence. The nominative case is related to the subject, the vocative case is for addressing, and the postposition comes after the noun and it includes all the other cases under the heading oblique. Consider the masculine singular noun mətt ${ }^{\mathrm{h}} \mathrm{u}$ 'boy': 
Figure 1: Declension

\begin{tabular}{|l|c|c|}
\hline \multirow{2}{*}{ Case } & \multicolumn{2}{|c|}{ Number } \\
\cline { 2 - 3 } & Singular & Plural \\
\hline Nominative & mətt $^{\mathrm{h}} \mathrm{u}$ & mətt $\mathrm{e}$ \\
\hline Oblique & $\operatorname{mott}^{\mathrm{h}} \mathrm{e}$ & $\mathrm{m}_{\mathrm{h}}^{\mathrm{h}} \mathrm{a}$ \\
\hline Vocative & mətt $^{\mathrm{h}} \mathrm{a}$ & mətt $^{\mathrm{h}} \mathrm{o}$ \\
\hline
\end{tabular}

For the word mətt ${ }^{\mathrm{h}} \mathrm{u}$ 'boy' the nominative plural and the oblique singular have a same form mətt ${ }^{\mathrm{h}} \mathrm{e}$, the oblique plural and the vocative singular have the same form mətt $\mathrm{t}^{\mathrm{h}} \mathrm{a}$, and the nominative singular and the vocative plural have the mett $t^{\mathrm{h}} u$ and mətt $^{\mathrm{h}} \mathrm{o}$ forms respectively. As we can see vowel alteration is also a process in addition to suffixation in the Bhadarwahi language.

5. matt $u$ g gre $^{\text {hat }}$ a ae boy.SG home.DO go.IMPF AUX.PRST

'The boy goes to home.'

6. matt ${ }^{\text {h }}$ g $g^{\text {h}}$ re ga:te $ә$ boy.PL home.DO go.IMPF AUX.PRST

'The boys go to home.'

7. mətt $^{\mathrm{h}} \mathrm{e} \tilde{\mathrm{I}}$ kəm kero

boy.SG ERG work do.PST

'The boy did the work.'

8. mətt $^{\mathrm{h}} \mathrm{e} \tilde{\mathrm{I}}$ kəm kero

boy.PL ERG work do.PST

'The boys did the work.'

9. $\quad$ mətt $t^{\text {ha }}$ ira ed3

$O$ boy.SG here come.IMP

'O boy, come here!'

10. o mətt ${ }^{\mathrm{h}} \mathrm{O}$ ira edza

$O$ boy.PL here come.IMP

'O boys, come here!'

\subsection{Adjectives}

Adjectives as qualifiers are of two types: variable and invariant. Variable inflects for number and gender; invariant remains same for number and gender. Adjectives, in direct form, end in /o/ in singular masculine gender, and /i/ in singular feminine gender. 


\subsubsection{Variable}

For ratro 'red':

Figure 2: For ratro 'red'

\begin{tabular}{|c|c|c|c|}
\hline \multicolumn{4}{|c|}{ Singular } \\
\hline \multicolumn{3}{|c|}{ M } & F \\
\hline Direct & Oblique & Direct & Oblique \\
\hline rətro 'red' & rətre 'red' & rətri 'red' & rətri 'red' \\
\hline
\end{tabular}

\begin{tabular}{|c|c|c|c|}
\hline \multicolumn{4}{|c|}{ Plural } \\
\hline \multicolumn{2}{|c|}{ M } & \multicolumn{2}{|c|}{ F } \\
\hline Direct & Oblique & Direct & Oblique \\
\hline ratre 'red' & rətre 'red' & retri 'red' & retri 'red' \\
\hline
\end{tabular}

Figure 3: For həro 'green'

\begin{tabular}{|c|c|c|c|}
\hline \multicolumn{3}{|c|}{ Singular } \\
\hline \multicolumn{2}{|c|}{ M } & \multicolumn{2}{c|}{ F } \\
\hline Direct & Oblique & Direct & Oblique \\
\hline həro 'green' & həre 'green' & həri 'green' & həri 'green' \\
\hline
\end{tabular}

\begin{tabular}{|c|c|c|c|}
\hline \multicolumn{4}{|c|}{ Plural } \\
\hline \multicolumn{2}{|c|}{ M } & \multicolumn{2}{c|}{ F } \\
\hline Direct & Oblique & Direct & Oblique \\
\hline həre 'green' & həre 'green' & heri 'green' & heri 'green' \\
\hline
\end{tabular}

Popularly used invariant adjectives are: bədfəkəl 'ugly', əgrəũ 'next', gol 'circular', sət] 'true', əmi:r 'rich', gəri:b 'poor', kəi 'many', dani 'benevolent' etc. The commonly used adverbs in Bhadarwahi language are: huni 'now', tet ${ }^{\mathrm{h}} \mathrm{a}: l i$ 'then', ket ${ }^{\mathrm{h}} \mathrm{a}: l i$ 'when', iri 'here', uri 'there', kori 'where', kent [ere 'how', kidzo 'why', hərdiha:re 'daily', logata:r 'continuosly', astə 'slowly', çupkerta 'silently', $\mathrm{t}^{\mathrm{h}} \mathrm{i}: \mathrm{k}-\mathrm{t}^{\mathrm{h}} \mathrm{a}: \mathrm{k}$ 'well' alike.

Numerals belong to the class of adjectives. They are divided into five types: cardinals, ordinals, multiplicatives, fraction, and aggregative. The functions (Abbi 2001:134) of numerals are following: 
Table 5: Numerals and their functions

\begin{tabular}{|l|l|}
\hline Numerals & Functions \\
\hline Cardinal & Pronouns or Modifiers \\
\hline Ordinal & Modifiers \\
\hline Multiplicative & Adverbs of frequency \\
\hline Fraction & Adverbs \\
\hline Aggregative & Nouns \\
\hline
\end{tabular}

Cardinals are numeral quantifiers used for counting. They are invariable in nature and they do not inflect for number and gender. Ordinals are used to show rank or ordering. They are formed by suffixation of / Jəũ/ to the base form. The feminine form shows $/ \widetilde{T} /$ suffixation, such as

10th: dəəũ, 20th: bijəũ, 30th: tlijəũ and 40th: çelijəũ. The multiplicatives are formed by suffixation 'gən' (which may inflect for person and gender) to cardinal numerals such as: 2 times: du + gəno = dugəno, 3 times:tli + gəno= tligəno, etc.

\subsection{Pronouns}

Pronouns are often used to refer to a noun that has already been mentioned. Pronoun morphoplogy is connected with the different forms of pronons, gender, number, animacy, and deictic categories.

\subsubsection{Personal pronouns}

Figure 4 shows personal pronouns.

Figure 4: Personal pronouns

\begin{tabular}{|c|c|c|}
\hline & Singular & Plural \\
\hline \multirow[t]{3}{*}{ First person } & әũ 'I’ (subject) & əsa 'we' (subject) \\
\hline & mĩ 'l' (ergative) & әseĩ 'we (ergative) \\
\hline & mero/i/e 'my' (possessive) & ifo/i/e 'our' (possessive) \\
\hline \multirow[t]{6}{*}{ Second person } & tu 'you' (subject) -HON & tu 'you' (subject) -HON \\
\hline & tus 'you' (subject) +HON & tusa 'you' (subject) +HON \\
\hline & tusəĩ 'you' (ergative) -HON & tuseĩ 'you' (ergative) -HON \\
\hline & tusəri 'you' (ergative) +HON & tuseĩ 'you' (ergative) +HON \\
\hline & təro/i/e 'you' (possessive) -HON & tero/i/e 'you' (possessive)-HON \\
\hline & tufo/i/e 'you'(possessive) +HON & tufõ/ĩ/ẽ 'you'(possessive) +HON \\
\hline
\end{tabular}




\begin{tabular}{|l|l|l|}
\hline & Singular & Plural \\
\hline \multirow{3}{*}{ Third person } & tu/u 'he/she' (subject) & ten 'they' (subject) -HON \\
\cline { 2 - 3 } & & tena 'they' (subject) +HON \\
\cline { 2 - 3 } & teni 'he' (ergative) & unei 'they' (ergative) \\
\cline { 2 - 3 } & tesa 'she' (ergative) & \multicolumn{1}{c|}{$/$} \\
\cline { 2 - 3 } & usero/i/e 'his/her' (poss.) & unkero/i/e 'their' (possessive) \\
\cline { 2 - 3 } & tesero/i/e 'his/her' (poss.) & tenkero/i/e 'their' (possessive) \\
\hline
\end{tabular}

\subsubsection{Definite and indefinite pronouns}

Figure 5 shows definite and indefinite pronouns.

Figure 5: Definite and indefinite pronouns

\begin{tabular}{|l|l|l|}
\hline \multirow{2}{*}{ Proximate } & \multicolumn{2}{|c|}{ Definite pronouns } \\
\cline { 2 - 3 } & \multicolumn{1}{|c|}{ Singular } & \multicolumn{1}{c|}{ Plural } \\
\cline { 2 - 3 } & in 'this' (subject) & ina 'these' (subject) \\
\cline { 2 - 3 } & ini 'this' (ergative) & ineĩ 'these' (ergative) \\
\cline { 2 - 3 } isero/i/e 'this' (possessive) & inkero/i/e 'these' (possessive) \\
\hline \multirow{3}{*}{ Remote } & te 'that' (subject) & ten 'those' (subject) \\
\cline { 2 - 3 } & teni/uni 'that' (ergative) & tenei/unei 'those' (ergative) \\
\cline { 2 - 3 } & tesero/usero/i/e 'that's' (poss.) & tenkero/unkero/i/e 'those' (poss.) \\
\hline \multirow{2}{|c|}{ Indefinite pronouns } \\
\cline { 2 - 3 } & \multicolumn{2}{|c|}{ Singular Plural } \\
\hline \multirow{2}{*}{} & koi 'someone' (subject) & koi 'someone' (subject) \\
\cline { 2 - 3 } & kentfi 'someone'(ergative) & kentfeĩ 'some' (ergative) \\
\cline { 2 - 3 } & kentf-ero/i/e 'someone's' (poss.) & kenkero/i/e'someone's.pl'(poss.) \\
\hline
\end{tabular}

\subsubsection{Relative pronouns}

Figure 6 shows relative pronouns.

Figure 6: Relative pronouns

\begin{tabular}{|l|l|}
\hline Singular & Plural \\
\hline zes 'whom' (subject) & zen 'whose' (subject) \\
\hline zeni 'whom' (ergative) & zeneĩ 'whose' (ergative) \\
\hline zesero/i/e 'whom' (possessive) & zenkero/i/e 'whose' (possessive) \\
\hline
\end{tabular}




\subsubsection{Interrogative pronouns}

Figure 7 shows interrogative pronouns.

Figure 7: Interrogative pronouns

\begin{tabular}{|l|l|}
\hline Singular & Plural \\
\hline kən 'who' (subject) & kəun 'whose' (subject) \\
\hline keni 'who' (ergative) & keneĩ 'who' (ergative) \\
\hline kesero/i/e 'whose' (possessive) & kenkero/i/e 'whose' (possessive) \\
\hline
\end{tabular}

\subsection{Verbs and verb morphology}

The verb is the heart of a sentence. It tells us about the time and nature of the event. The nature of nominal expressions (requires one nominal expression or two) is determined by a verb. In imperative the subject remains elliptical but recoverable from the verb. Lexical verbs, conjunct verbs, auxiliary verbs, and compound verbs are discussed below. Following are the examples:

The base form $\mathrm{k}^{\mathrm{h}} \mathrm{\partial}$ 'eat' admits the following forms:

\begin{tabular}{|l|c|c|}
\hline & Singular & Plural \\
\hline Masculine & $\mathrm{k}^{\mathrm{h}} \mathrm{r}$ & $\mathrm{k}^{\mathrm{h}} \mathrm{at}$ \\
\hline Feminine & $\mathrm{k}^{\mathrm{h}} \partial$ & $\mathrm{k}^{\mathrm{h}} \mathrm{at}$ \\
\hline
\end{tabular}

The habitual form (by imperfective) is generated by the addition of a base / $\mathrm{t} /$ to which is added the gender and number suffixes: $0, a e, i$, and ie. Thus, the base form $k^{\text {h}} \partial$ 'eat' admits the following:

\begin{tabular}{|l|c|c|}
\hline & Singular & Plural \\
\hline Masculine & $\mathrm{k}^{\mathrm{h}}$ ato & $\mathrm{k}^{\mathrm{h}}$ atae \\
\hline Feminine & $\mathrm{k}^{\mathrm{h}} \mathrm{ati}$ & $\mathrm{k}^{\mathrm{h}}$ atie \\
\hline
\end{tabular}

The habitual aspect has these verbal forms: $\mathrm{X}$-to, $\mathrm{X}$-ti, and $\mathrm{X}$-te where $\mathrm{X}$ is the verbal root. X-to form comes with masculine first person singular əũ ' $I$ ', with masculine third person singular (or any noun person) te 'he', and with masculine second person tu 'you'. X-ti form comes with feminine first person singular əũ ' 1 ', with feminine third person singular (or any noun person) te 'she', with feminine first person plural, and with feminine second person tu 'you.' X-te form comes with masculine first person plural, masculine second person plural/honorific and masculine third person plural. But we find variations in the auxiliaries of above mentioned $\mathrm{X}$-to, $\mathrm{X}$-ti, and $\mathrm{X}$-te verbal form for habitual aspect. The following table precisely captures this difference: 
Table 6: Habitual Aspect

\begin{tabular}{|c|c|c|c|}
\hline Person \& Number & $\begin{array}{c}\text { Verbal Form } \\
\text { (Aspect marker) }\end{array}$ & $\begin{array}{c}\text { Auxiliary Form } \\
\text { (Present Tense } \\
\text { marker) }\end{array}$ & $\begin{array}{c}\text { Auxiliary Form } \\
\text { (Past Tense } \\
\text { marker) }\end{array}$ \\
\hline $\begin{array}{l}\text { Masculine First Person } \\
\text { Singular }\end{array}$ & X-to & ã̃ & $t^{\mathrm{h}} \mathrm{u}$ \\
\hline $\begin{array}{l}\text { Masculine Third Person } \\
\text { Singular }\end{array}$ & $X$-to & ae & $t^{\mathrm{h}} \mathrm{u}$ \\
\hline $\begin{array}{l}\text { Masculine Second } \\
\text { Person }\end{array}$ & $X$-to & əs & $t^{\mathrm{h}} \mathrm{u}$ \\
\hline $\begin{array}{l}\text { Feminine First Person } \\
\text { Singular }\end{array}$ & $x-t i$ & aĨ & $\mathrm{t}^{\mathrm{h}_{\mathrm{i}}}$ \\
\hline $\begin{array}{l}\text { Feminine Third Person } \\
\text { Singular }\end{array}$ & $X-t i$ & ae & $t^{h_{i}}$ \\
\hline $\begin{array}{l}\text { Feminine Second Person } \\
\text { singular }\end{array}$ & $X-t i$ & əS & $t^{h_{i}}$ \\
\hline $\begin{array}{l}\text { Feminine Second Person } \\
\text { plural/honorific }\end{array}$ & $X-t i$ & $\partial t^{h}$ & $\mathrm{t}^{\mathrm{h}} \mathrm{i}:$ \\
\hline $\begin{array}{l}\text { Feminine First Person } \\
\text { Plural }\end{array}$ & $X-t i$ & әm & $\mathrm{t}^{\mathrm{h}} \mathrm{i}:$ \\
\hline $\begin{array}{l}\text { Masculine First Person } \\
\text { Plural }\end{array}$ & $X$-te & әm & $t^{h}$ ie \\
\hline $\begin{array}{l}\text { Masculine Second Person } \\
\text { plural/honorific }\end{array}$ & $X$-te & $\partial t^{h}$ & $\mathrm{t}^{\mathrm{h}} \mathrm{ie}$ \\
\hline $\begin{array}{l}\text { Masculine Third Person } \\
\text { Plural }\end{array}$ & X-te & ən & $t^{\mathrm{h}} \mathrm{ie}$ \\
\hline
\end{tabular}

The perfective form is generated by the addition of a base / $a /$ to which is added the gender and number suffixes: $u, i$, and $u$ when the verb agrees with the subject.

\begin{tabular}{|l|c|c|}
\hline & Singular & Plural \\
\hline Masculine & $\mathrm{k}^{\mathrm{h}} \mathrm{au} / \mathrm{i}$ & $\mathrm{k}^{\mathrm{h}} \mathrm{au} / \mathrm{i}$ \\
\hline Feminine & $\mathrm{k}^{\mathrm{h}} \mathrm{ai} / \mathrm{u}$ & $\mathrm{k}^{\mathrm{h}} \mathrm{au} / \mathrm{i}$ \\
\hline
\end{tabular}

When the verb agrees with object (feminine):

\begin{tabular}{|l|c|c|}
\hline & Singular & Plural \\
\hline Masculine & $\mathrm{k}^{\mathrm{h}}$ i & $\mathrm{k}^{\mathrm{h}} \mathrm{ei}$ \\
\hline Feminine & $\mathrm{k}^{\mathrm{h}} \mathrm{ai}$ & $\mathrm{k}^{\mathrm{h}} \mathrm{ei}$ \\
\hline
\end{tabular}


When the verb agrees with object (masculine):

\begin{tabular}{|l|c|c|}
\hline & Singular & Plural \\
\hline Masculine & $\mathrm{k}^{\mathrm{h}} \mathrm{au}$ & $\mathrm{k}^{\mathrm{h}} \mathrm{ae}$ \\
\hline Feminine & $\mathrm{k}^{\mathrm{h}} \mathrm{au}$ & $\mathrm{k}^{\mathrm{h}} \mathrm{ae}$ \\
\hline
\end{tabular}

Table 7: Perfective aspect

\begin{tabular}{|c|c|c|c|c|c|c|c|}
\hline \begin{tabular}{|l|} 
Perfective \\
Aspect Form
\end{tabular} & I.M & I.F & We.M & We.F & $\begin{array}{l}\text { You } \\
\text { SG.M }\end{array}$ & $\begin{array}{l}\text { You } \\
\text { SG.F }\end{array}$ & $\begin{array}{l}\text { You } \\
\text { PL.M }\end{array}$ \\
\hline 'e & $\mathrm{k}^{\mathrm{h}} \mathrm{au}$ & $\mathrm{k}^{\mathrm{h}} \mathrm{eI}$ & $k^{h} a I$ & $k^{h}$ eI & $k^{h} a I$ & $k^{h}$ eI & $k^{h} a I$ \\
\hline 'sleep' & $\mathrm{z}^{\mathrm{h}} \mathrm{zlo}$ & $z^{\text {hulI }}$ & $z^{\text {hule }}$ & $\mathrm{z}^{\mathrm{h}} \mathrm{ulI}$ & $z^{\text {hulo }}$ & $z^{\text {hulI }}$ & $z^{\text {hule }}$ \\
\hline 'run' & dowəro & dowərI & dowəre & dewərI & dowəro & dowərI & dowəre \\
\hline 'fall' & JIgo & fIgI & fIge & fIgI & figo & fIgI & frge \\
\hline 'understand' & səmzo & səmzI & səmze & səmzI & səmzo & səmzI & səmze \\
\hline 'see' & hero & heru & hero & heru & hero & heru & hero \\
\hline 'drink' & pIw & prji & prw & pтjI & piw & pтji & pIW \\
\hline 'bath' & nəhəu & nihəu & nəhəu & nihəu & nəhəu & nihəu & nəhəu \\
\hline 'write' & II $k^{h} \mathrm{O}$ & II $k^{h} u$ & IIk ${ }^{\mathrm{h}} \mathrm{O}$ & $\operatorname{lik}^{h} u$ & IIt $\mathrm{k}^{\mathrm{h}} \mathrm{O}$ & $\operatorname{lIk}^{h} \mathrm{u}$ & II $\mathrm{K}^{\mathrm{h}} \mathrm{O}$ \\
\hline \begin{tabular}{|l|} 
Perfective \\
Aspect Form
\end{tabular} & $\begin{array}{l}\text { You } \\
\text { PL.F }\end{array}$ & $\begin{array}{l}\text { You } \\
\text { HON.M }\end{array}$ & $\begin{array}{l}\text { You } \\
\text { HON.F }\end{array}$ & $\mathrm{He}$ & She & $\begin{array}{l}\text { They } \\
\text { M }\end{array}$ & \begin{tabular}{|l} 
They \\
F
\end{tabular} \\
\hline 'eat' & $k^{h} e I$ & $k^{h} a: I$ & $k^{h} e I$ & $k^{h} a_{I}$ & $k^{h} e I$ & $k^{h} a: I$ & $k^{h} e: I$ \\
\hline 'sleep' & $z^{\text {hulI }}$ & $z^{\text {h }}$ ule & $z^{\text {h }}$ ulI & $z^{\text {h }}$ ulo & $z^{\text {h } u l s}$ & $z^{\text {h ule: }}$ & $z^{\text {huls }}$ \\
\hline 'run' & dewərI & dowəre & dowərI & dowəro & dowərI & dowəre: & dewərI \\
\hline 'fall' & fIgI & frge & fIgI & fIgp & fIgI & fIge: & frgi: \\
\hline 'understand' & səmzI & səmz $z^{\text {he }}$ & səmz ${ }^{h_{I}}$ & səmzo & səmzI & səmz ${ }^{\mathrm{h}} \mathrm{e}$ & semz ${ }^{h_{I}}$ \\
\hline 'see' & heru & he:ro & he:ru & hero & heru & he:ro & he:ru \\
\hline 'drink' & prji & pi:w & pi:ji & pIw & prji & pi:w & pi:ji \\
\hline 'bath' & nihau & nəhau & nIhau & nəhau & nihau & nəhau & nrhau \\
\hline 'write' & II $k^{h} u$ & IIk $k^{\text {ho: }}$ & IIk $u:$ & II k $k^{h} \mathrm{O}$ & II $k^{h} u$ & IIk & II $\mathrm{k}^{\mathrm{h}} \mathrm{u}$ : \\
\hline
\end{tabular}

The progressive form is generated by the combination of a base /roor/ to which is added the gender and number suffixes: $o, e, i$, and $i$, and the auxiliary forms which we will discuss in the following heading: auxiliary.

\begin{tabular}{|l|c|l|}
\hline & Singular & Plural \\
\hline Masculine & rəoro & rəore \\
\hline Feminine & rəori & reori: \\
\hline
\end{tabular}


11. ramej au

Ramesh come.PST

'Ramesh came.'

12. rəme $\mathrm{i}$ kəm kero

Ramesh ERG work do.PST

'Ramesh did the work.'

A verb like kerno 'to do' requires two nominal expressions as in (12).

13. rəme $\mathrm{i}$ həri-e/dzo peĩso ditto

Ramesh ERG Hari-IO/OBL money give.PST

'Ramesh gave money to Hari.'

A verb like deno 'to give' requires three nominal expressions as in (13).

Table 8: Progressive aspect

\begin{tabular}{|c|c|c|c|}
\hline Person \& Number & $\begin{array}{c}\text { Verbal Form } \\
\text { (Aspect marker) }\end{array}$ & $\begin{array}{c}\text { Auxiliary Form } \\
\text { (Present Tense } \\
\text { marker) }\end{array}$ & $\begin{array}{c}\text { Auxiliary Form } \\
\text { (Past Tense } \\
\text { marker) }\end{array}$ \\
\hline $\begin{array}{l}\text { Masculine First Person } \\
\text { Singular }\end{array}$ & X-ro & ã̃ & $t^{h} u$ \\
\hline $\begin{array}{l}\text { Masculine Third Person } \\
\text { Singular }\end{array}$ & X-ro & ae & $t^{h} \mathrm{u}$ \\
\hline $\begin{array}{l}\text { Masculine Second Person } \\
\text { Singular }\end{array}$ & X-ro & ae & $\mathrm{t}^{\mathrm{h}} \mathrm{u}$ \\
\hline $\begin{array}{l}\text { Feminine First Person } \\
\text { Singular }\end{array}$ & X-ri & ã̃ & $t^{h_{i}}$ \\
\hline $\begin{array}{l}\text { Feminine Third Person } \\
\text { Singular }\end{array}$ & X-ri & ae & $t^{h_{i}}$ \\
\hline $\begin{array}{l}\text { Feminine Second Person } \\
\text { singular }\end{array}$ & X-ri & ae & $t^{h_{i}}$ \\
\hline $\begin{array}{l}\text { Feminine Second Person } \\
\text { plural/honorific }\end{array}$ & X-ri & $\partial t^{h}$ & $\mathrm{t}^{\mathrm{h}_{\mathrm{i}}}$ \\
\hline $\begin{array}{l}\text { Feminine First Person } \\
\text { Plural }\end{array}$ & X-ri & әm & $\mathrm{t}^{\mathrm{h}_{\mathrm{i}}}$ \\
\hline $\begin{array}{l}\text { Masculine First Person } \\
\text { Plural }\end{array}$ & X-re & әm & $\mathrm{t}^{\mathrm{h}} \mathrm{ie}$ \\
\hline $\begin{array}{l}\text { Masculine Second Person } \\
\text { plural/honorific }\end{array}$ & X-re & $\partial t^{h}$ & $t^{\mathrm{h}} \mathrm{ie}$ \\
\hline $\begin{array}{l}\text { Masculine Third Person } \\
\text { Plural }\end{array}$ & X-re & ən & $t^{\mathrm{h}} \mathrm{ie}$ \\
\hline
\end{tabular}




\subsubsection{Compound verbs}

In Bhadarwahi when two verbal elements are used to express a single meaning; it is constructed by a compound verb. The first verb in the verbal carries the primary meaning or the main meaning (semantic), and the second verb only modifies the primary verb. The second verb marks for number, person, and gender (grammatical), and the first verb comes in the non-honorific imperative invariant form.

\subsubsection{Compounds with ga:no 'to go'}

The ga:no 'to go' occurs frequently with many verbs, for example: k ei ga:no 'to eat',

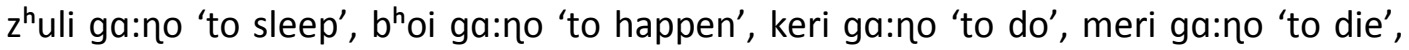
etc.

14. koskoi-koskoi ero b $b^{\text {hoto }}$ Sometimes this happen.IMPF AUX.PRST

'Sometimes this happens.'

15. koskoi-koskoi ero $b^{\text {hoi }}$ ga:to ae Sometimes this happen go.IMPF AUX.PRST

'Sometimes this happens.'

16. mere edzte ei $u / t e k^{h i j k i}$ dzew

my.POSS come.IMPF EMPF he crawl go.PST

'He left as I came.'

17. te/u meri dzew

he.III.SG die go.PST

'He died.'

In (14) the verb bhoto 'to happen' is intransitive, but the compound verb $b^{\text {hoi ga:to }}$ 'to happen' in (15) gives it a special suggestive meaning which cannot be expressed by the (14). In (16) the compound verb shows an immediacy of action, and in (17) it shows the completion of an action.

\subsubsection{Compounds with edzəno 'to come'}

Another verb edzəno 'to come' occurs frequently with many verbs, for example: $b^{\text {h }}$ oi edzəno 'to happen', nə]i edzəno 'to run', keri edzəno 'to do', nissi edzəno 'to pass', etc.

18. tu kla:si mə rə dzəldi nissi edza

you.II.SG class in from early pass come.IMP

'You come from the class early.'

Generally the compound verb with edzəno 'to come' directs two actions the first verb carries the main meaning and the second verb includes suggestiveness to the meaning. 


\subsubsection{Compounds with çəddəno 'to put'}

Another verb çəddəno 'to put' occurs frequently with many verbs, for example: tlori çəddəno 'to crush', t $\int \mathrm{u}: \int \mathrm{i}$ çəddəno 'to suck', meri çəddəno 'to kill', keri çəddəno 'to do', k holi çəddəno 'to open', etc.

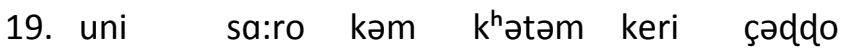

he.OBL all work finish do put.PST

'He finished all the work.'

The compound verb with çəddəno 'to put' comes with transitive verbs.

Compounds are also formed with neno 'to take', deno 'to give', rək həno 'to put', pəno 'to fall', urno 'to get up', bifəno 'to sit', etc.

20. te hassi pei

he.3.SG bloom.REDUP laugh fall.PST

'He had a belly laugh.'

21. rəwi ət $\int a: n ə k$ $u t^{h_{i}} k^{h} \partial r_{0} b^{h} u o$

Ravi suddenly get stand happen.PST

'Ravi stood suddenly.'

\subsubsection{Conjunct verb}

This consists of a noun or an adjective and a verbal element such as: zəba:n deni 'to promise' (literal meaning is 'to give tongue'), hət ${ }^{\text {h }}$ deno 'to marry' (literal meaning is 'to give hand') and da:n deno 'to donate' (literal meaning is 'to donate').

The behavior of conjunct verbs can be compared with English phrasal verbs i.e. they are metaphorical in meaning. The conjunct verbs are employed in the following sentences where they give the metaphorical meaning:

22. Jərma: ho:r i suref-e əpni kuij ero het ditto Sharma HON ERG Suresh-IO his.POSS daughter of hand give.PST 'Mr. Sharma married his daughter to Suresh.'

23. mero to sənsar era dil $b^{\text {heri }}$ dzewro ae my.POSS EMP world from heart fill go.PST AUX.PRST 'I am fed up with this world.'

The conjunct verbs in (22) \& (23) have a metaphorical meaning. In (22) the verb het ${ }^{\text {h }}$ ditto has a connotative meaning when a father selects a person for her daughter to get married. 
There are sentences when the noun of a conjunct verb agrees with the object as in (24) \& (25):

24. teni mətt $t^{\mathrm{h}}$ ero $\mathrm{k}^{\mathrm{h} i j a: I}$ rək $^{\mathrm{h}} \mathrm{o} \quad \mathrm{t}^{\mathrm{h}} \mathrm{u}$ :

He.ERG child.POSS care put.PERF AUX.PST

'He took care of the child.'

25. iri mətt ${ }^{h} a$ : kero $k^{h_{i j a}}$ :I rək ${ }^{h} o$ ga:to ae here child.PL of care put.PERF go.IMPF AUX.PRST

'Here children are being taken care of.'

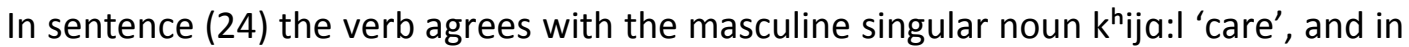
(25) $\mathrm{k}^{\mathrm{h}} \mathrm{ija}: \mathrm{I}$ 'care' agrees with the verbal complex rək ${ }^{\mathrm{h}} \mathrm{o}$ ga:toae.

\subsubsection{Auxiliary verbs}

In Bhadarwahi the auxiliary verbs are used to mark present and past, they are of two types: base $/ \mathrm{t}^{\mathrm{h}}$ / (in present tense) which inflects for the gender and number suffixes: $/ \mathrm{a} /$ and $/ \mathrm{\partial} /$, and $\mathrm{u}, \mathrm{ie}, \mathrm{i}$, and $\mathrm{i}$ : (in past tense) which inflects for the gender and number suffixes: e and $ə n$. The future tense is marked on the main verb by base /I/ which inflects for the gender and number: $o, e, i$, and $i:$.

\begin{tabular}{|l|c|c|}
\hline \multirow{2}{*}{ Masculine } & Singular & Plural \\
\cline { 2 - 3 } & ae & कn \\
\hline Feminine & ae & ən \\
\hline \multirow{2}{*}{} & Singular & Plural \\
\cline { 2 - 3 } & $\mathrm{t}^{\mathrm{h}} \mathrm{u}$ & $\mathrm{t}^{\mathrm{h}} \mathrm{ie}$ \\
\hline & $\mathrm{t}^{\mathrm{h}} \mathrm{i}$ & $\mathrm{t}^{\mathrm{h}} \mathrm{i}:$ \\
\hline
\end{tabular}

The presumptive form is with a base $/ \mathrm{b}^{\mathrm{h}} \mathrm{o} /$ inflects for the gender and number suffixes: $0, e, i$, and $i$ :.

\begin{tabular}{|l|c|c|}
\hline \multirow{2}{*}{} & \multicolumn{2}{|c|}{ Presumptive } \\
\cline { 2 - 3 } & Singular & Plural \\
\hline Masculine & $\mathrm{b}^{\text {h }}$ oto & $\mathrm{b}^{\text {h}}$ ote \\
\hline Feminine & $\mathrm{b}^{\mathrm{h}}$ oti & $\mathrm{b}^{\text {hoti }}$ \\
\hline
\end{tabular}




\subsubsection{Verb Inflection}

Bhadarwahi verbs exhibit the following inflection:

Root

Infinitive

Imperfective participle (Masculine)

Imperfective participle (Feminine)

Perfective participle (Masculine)

Perfective participle (Feminine)

Causative (I)

Causative (II) pər 'read'

pərno

pərto

pərti

pəro

pəri

pərhanu (cause $X$ to $V$ )

perwahanu (cause $Y$ to cause $X$ to $V$ )

Figure 8: Verb inflection for verbs

\begin{tabular}{|c|c|c|c|c|c|}
\hline Root & $\begin{array}{l}\text { Base form for } \\
\text { infinitive }\end{array}$ & $\begin{array}{l}\text { Base form for } \\
\text { imperfective }\end{array}$ & $\begin{array}{l}\text { Base form for } \\
\text { perfective }\end{array}$ & $\begin{array}{l}\text { Base form for } \\
\text { causative-I }\end{array}$ & $\begin{array}{l}\text { Base form for } \\
\text { causative-II }\end{array}$ \\
\hline pər & $\begin{array}{l}\text { base } / \mathrm{n} / \text { and } \\
\text { suffixes o, e, i, } \\
\text { ĩ, u are added } \\
\text { for number } \\
\text { and gender }\end{array}$ & $\begin{array}{l}\text { base /t/ and } \\
\text { suffixes o, i, e, } \\
\text { i, } u \text { are added } \\
\text { for number } \\
\text { and gender }\end{array}$ & $\begin{array}{l}\text { base } / r / \text { and } \\
\text { suffixes o, i, e, } \\
\text { i, u are added } \\
\text { for number } \\
\text { and gender }\end{array}$ & $\begin{array}{l}\text { base /han/ } \\
\text { and suffixes o, } \\
\text { i, e, ĩ, u are } \\
\text { added for } \\
\text { number and } \\
\text { gender }\end{array}$ & $\begin{array}{l}\text { base /wahan/ } \\
\text { and suffixes o, } \\
\text { i, e, Ĩ, u are } \\
\text { added for } \\
\text { number and } \\
\text { gender }\end{array}$ \\
\hline \begin{tabular}{|l} 
Root \\
Meaning \\
\end{tabular} & Infinitive & Imperfective & Perfective & $\begin{array}{l}\text { Causative (I) } \\
\text { Participle }\end{array}$ & $\begin{array}{l}\text { Causative (II) } \\
\text { Participle }\end{array}$ \\
\hline $\begin{array}{l}\text { por } \\
\text { read }\end{array}$ & parno & $\begin{array}{l}\text { parto (M) } \\
\text { pərti (F) }\end{array}$ & $\begin{array}{l}\text { pəro (M) } \\
\text { pəri (F) }\end{array}$ & prano & pərwano \\
\hline $\begin{array}{l}\text { ut } \\
\text { stand }\end{array}$ & ut ${ }^{\mathrm{h}}$ əno & $\begin{array}{l}\text { ut }{ }^{\text {h }} \text { to }(\mathrm{M}) \\
\mathrm{ut}{ }^{\mathrm{h}} \text { ti (F) } \\
\end{array}$ & $\begin{array}{l}\mathrm{utt}^{\mathrm{h}} \mathrm{o}(\mathrm{M}) \\
\mathrm{utt}^{\mathrm{h}} \mathrm{i}(\mathrm{F}) \\
\end{array}$ & $u t^{\text {h }}$ ano & $u t^{\text {h }}$ wano \\
\hline $\begin{array}{l}\text { ən } \\
\text { bring }\end{array}$ & әпno & $\begin{array}{l}\text { onto (M) } \\
\text { onti (F) }\end{array}$ & $\begin{array}{l}\text { әno (M) } \\
\text { əทi (F) }\end{array}$ & / & әnwano \\
\hline \begin{tabular}{|l|} 
uzər \\
devastate
\end{tabular} & uzərno & $\begin{array}{l}\text { uzərto (M) } \\
\text { uzarti (F) }\end{array}$ & $\begin{array}{l}\text { uzəro (M) } \\
\text { uzəri (F) }\end{array}$ & uzarno & uzərwano \\
\hline $\begin{array}{l}\text { uçər } \\
\text { jump }\end{array}$ & uçərno & uçərto (M) & uçəro (M) & uçarno & uçərwano \\
\hline
\end{tabular}

\section{Basic syntax}

Bhadarwahi simple sentence is a combination of subject and predicate. A simple sentence consists of one main clause only. The predicate of a sentence contains the verb (it optionally consists of objects also) and gives information about the subject. The predicate is typically the structure that follows the subject. 


\subsection{Word order}

Bhadarwahi is a subject dominant language with an SOV word order (SV if without object). Its subject comes in the first place, an object comes in the middle, and the verb comes in the final position.

26. sərita dzəmoro-dud $k^{\text {h }} a$ :ti ae

Sarita frozen-milk.O eat.IMPF Aux.PRST

'Sarita eats curd.'

The subject sərita 'Sarita' comes first in the sentence. The object dzəməro-dudə 'curd' comes in the middle, and verb $\mathrm{k}^{\mathrm{h}} \mathrm{a}$ :ti ae 'eats' comes in the last. In English the order of object and verb is inverted from OV to VO. Here the verb $k^{\mathrm{h}} \mathrm{a}$ :ti ae 'eats' agrees with the subject sorita 'Sarita', and it is without an overt case-marker. We can also write the sentence (26) such as:

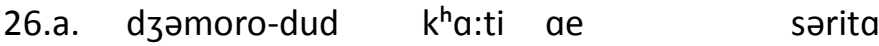
frozen-milk eat Aux.PRST.SG Sarita

'Sarita eats curd.'

26.b. dzəmoro-dud sorita $k^{\text {h}} a: t i$ ae frozen-milk Sarita eat Aux.PRST.SG

'Sarita eats curd.'

The word order in Bhadarwahi is flexible to an explanation for the subject and the object. The word order of an assertive, negative, interrogative, and imperative remain different from each other. The changes in person, number, gender, case, aspect, tense, and mood are also observed in the Bhadarwahi language.

\subsection{Subject-verb agreement}

Bhadarwahi verb agrees with a noun phrase which is not followed by an overt postposition. Unless there is a post-position after the subject of a sentence, the verb will agree with the subject in person, number and gender. The subject NP triggers the agreement. Consider the following sentences:

27. bepu dzi hər beri vaifənu dewi ga:te ən

father HON every year Vaishno Devi go.IMPF AUX.PRST.PL

'Father visits Vaishno Devi every year.'

The subject is third person singular honorific bepu dzi 'father' in (27) and the verb is accordingly marked plural ga:te 'go', and the auxiliary ən marks tense and plural, and it also shows that honorific singular subjects are marked plural.

28. mohən kəne səlma peni sei $k^{\text {hedi }}$ rəore ən Mohan and Salma water from play live.PROG AUX.PRST.PL

'Mohan and Salma are playing with water.' 
The subject in (28) has two III person singular nouns mohən 'Mohan' and səlma 'Salma'conjunct with kəne 'and', which constitute a plural subject. The verb and auxiliary (a tense marker) is marked plural accordingly.

29. ma:stər dzi bəre bəle zote ən teacher HON very slowly say AUX.PRST.PL

'The teacher speaks very slowly.'

The subject in (29) is a third person singular honorific and the verb and auxiliary (a tense marker) is marked plural (honorific gets a plural verb form). The modifier bəre 'very' and adverb bəle 'slowly' agrees with the verb zote 'say'.

$\begin{array}{llllll}\text { 30. tus har diha:re tesere } & \text { ka: } & \text { ga:te } & \text { ət } \\ \text { you.2.SG daily day } & \text { him } & \text { near go } & \text { AUX.PRST } \\ \text { 'You go to him every day.' } & & & & \end{array}$

The subject in (30) is a second person singular pronoun. Bhadarwahi has three different words for second person reflecting politeness hierarchy like Hindi. They are:

tu 'you' (an impolite form),

tus 'you' (more polite), and

tusa'you' similar to ap 'you' in Hindi (the most polite)

31. sərita əĩ kukəri eri rotti $k^{\text {h }}$

Sarita ERG maize of chapatti eat.PST

'Sarita ate a chapatti made of maize.'

As we can see in (31) that noun phrase sərita is followed by an overt post-position əĩ that is an ergative marker. The verb $\mathrm{k}^{\mathrm{h}}$ əi 'ate' agrees with object-head rotti 'chapatti. The object-head 'chapatti is a feminine noun and that's why we have verb form $\mathrm{k}^{\mathrm{h}}$ əi 'ate' and not k $\mathrm{k}^{\mathrm{h}} \mathrm{w}$ 'ate' which is used for masculine.

\section{Typological overview}

The major typological features of the Bhadarwahi language have been summarized and presented in Table 9:

Table 9: Some typological features of Bhadarwahi

\begin{tabular}{|l|l|}
\hline Grammatical features & Types of features \\
\hline Unmarked clause order & SOV \\
\hline Direct/Indirect object & Indirect object precedes the direct object \\
\hline Adposition & Postposition \\
\hline Genitive noun & Genitive precedes noun \\
\hline Deictic system & Proximate/distal \\
\hline
\end{tabular}




\begin{tabular}{|l|l|}
\hline Grammatical features & Types of features \\
\hline Adjective & $\begin{array}{l}\text { Adjective-Head, the adjective follows the standard } \\
\text { of comparison }\end{array}$ \\
\hline Verb affixes & Mainly prefixing, also suffixing, infixing in causatives \\
\hline Agreement & \\
\hline
\end{tabular}

\section{Conclusion}

The paper summarizes some grammatical features of the Bhadarwahi language. Due to prolonged contact with Hindi, Dogri and Kashmiri speakers, the natives of Doda and Bhadarwah have borrowed script and few lexical items from these languages. Despite this, Bhadawahi is a different language and the language does not show any mutual intelligibility with Dogri, Hindi and Kashmiri. However, other languages spoken it the region such as Pangwali, Siraji, Padri and Bhalesi show lexical similarity up to fifty to fifty five percent.

\section{REFERENCES}

Abbi, Anvita. A Manual of Linguistic Field Work and Indian Language Structures. (Lincom Handbooks in Linguistics 17) Munich: Lincom Europa.2001. Print.

Cambell, L. C. Concise Compendium of World's Language. London: Routledge. 1995. Print.

Chelliah, L. Shobhana and Reuse De J. Willem. Handbook of Descriptive Linguistic Fieldwork. London: Springer Dordrencht Heidelberg. 2011. Print.

Comrie, Bernard. Language Universals and Linguistic Typology. $2^{\text {nd }}$ edition. Oxford: Blackwell and Chicago: University of Chicago Press. 1989. Print.

Comrie, B. (Ed.) The World's Major Languages. NY: Routledge.1989. Print.

Dwivedi, Amtiabh Vikram. (2013) A Grammar of Bhadarwahi. Munchen: Lincom Europa, Print.

Greenberg, Joseph H. Language Typology: A Historical and Analytic Overview. The Hague Mouton. 1974. Print.

Grenoble, A. Lenone. and Whaley, J. Lindsay. Saving languages: An introduction to language revitalization.UK: CUP. 2006. Print.

Grierson, George A. Linguistic Survey of India: Vol. Viii. Delhi [Delhi: Motilal Banarsidass, 1968. Print.

Guru, KamtaPrasad. HindiVyakaran. [Hindi Grammar] Varanasi: NagariPracharini Sabha.1919. (1962 edition). Print. 
Lewis, M. Paul. ed. Ethnologue: Language of the World, Sixteen edition. Dallas, Tex: SIL Internatioanl.2009.Web.20Dec.2021.

http://www.ethnologue.com/show_language.asp?code=bhd

Masica, Colin P. Defining a Linguistic Area: South Asia. Chicago: Chicago University Press. 1976. Print.

Masica, Colin P. Indo-Aryan Languages. NY ;Cambridge University Press.1991.Print. 